DOI 10.37882/2223-2982.2021.09.12

\title{
ДОСУГОВАЯ ДЕЯТЕЛЬНОСТЬ НА ОСНОВЕ ЭТНОКУЛЬТУРНОГО МАТЕРИАЛА КАК СРЕДСТВО ФИЗИЧЕСКОГО РАЗВИТИЯ ДОШКОЛЬНИКОВ ${ }^{1}$
}

\section{LEISURE ACTIVITIES BASED ON ETHNOCULTURAL MATERIAL AS A MEANS OF PHYSICAL DEVELOPMENT OF PRESCHOOLERS}

E. Kirkina

O. Taraskina

Summary: Protection and strengthening of the physical health of preschool children is the most important task of a preschool educational institution. In this regard, research that identifies the conditions, content and methods of work for the physical development of preschoolers is of priority importance. The article deals with the issues of physical education of preschoolers in leisure activities, including ethnocultural material.

Keywords: physical education, physical development, preschool age, leisure activities, preschool pedagogy.
$\mathrm{H}$ а современном этапе физическому воспитанию детей тесно связанному с процессом умственного, нравственного, эстетического воспитания, в дошкольных образовательных организациях уделяется приоритетное внимание.

Система физического воспитания в дошкольной организации сегодня по-прежнему носит классический характер. Ее основой, в первую очередь, является оригинальная теория физического воспитания крупнейшего ученого-педагога П.Ф. Лесгафта, а также исследования других отечественных ученых (В.В. Гориневского, Л.И. Чулицкой, Е.А. Аркина, Н.А. Метлова, Е.Г. Леви-Гориневской, Н.И. Озерецкого и др.) [3].

Традиционно основное место в планировании деятельности дошкольных учреждений по физическому воспитанию отводится таким формам как занятия, утренняя гимнастика, игры и упражнения на прогулке, физкультминутки. Однако такая форма как физкультурный досуг обладает огромным потенциалом в сфере физического воспитания дошкольников. Физкультурный досуг - интересное, яркое, веселое событие в будничной
Киркина Елена Николаевна

к.филол.н., дочент, ФГБОУ ВО «Мордовский государственный педагогический университет им. М.Е. Евсевьева», г. Саранск kirkinaelena@yandex.ru

Тараскина Ольга Игоревна ФГБОУ ВО «Мордовский государственный педагогический университет им. М.Е. Евсевьева», г. Саранск olga.taraskina2001@yandex.ru

Аннотация: Охрана и укрепление физического здоровья детей дошкольного возраста важнейшая задач дошкольного образовательного учреждения. В связи с этим, приоритетное значение имеют исследования, выявляющие условия, содержания и методы работы по физическому развитию дошкольников. В статье рассмотрены вопросы физического воспитания дошкольников в досуговой деятельности, включающей этнокультурный материал.

Ключевые слова: физическое воспитание, физическое развитие, дошкольный возраст, досуговая деятельность, дошкольная педагогика.

жизни, сопровождающееся высокой двигательной активностью детей [2].

В последние десятилетия особое внимание педагогов дошкольного образования акцентируется на использование этнокультурного материала в практической деятельности, в том числе и в процессе физического воспитания детей $[1$, с.6]. Физкультурный досуг позволяет успешно решать задачи по приобщению детей к этнокультурному наследию родного края, национальной культуре, активно использовать региональный компонент в процессе физического воспитания дошкольников, учитывая этнокультурную ситуацию развития детей. Физический досуг на основе этнокультурного материала решает триаду задач физического воспитания: оздоровительных, воспитательных и образовательных. В содержание таких досуговых мероприятий включаются народные игры, забавы, произведения малых фольклорных форм, народные песни, считалки, загадки, содержание которых связано с физическим воспитанием.

Планируются физкультурные досуги на основе этнокультурного материала с учетом возрастных особен-

1 Исследование выполнено в рамках гранта на проведение научно-исследовательских работ по приоритетным направлениям научной деятельности вузов-партнеров по сетевому взаимодействию (УлГПУ и МГПИ) по теме «Подготовка будущих педагогов дошкольного образования к работе по физическому воспитанию дошкольников». 
ностей и двигательных возможностей детей. В младшем дошкольном возрасте проводятся элементарные игры с различными поручениями, хороводные народные игры. Со старшими дошкольниками досуги проводятся в форме соревнований, игр-забав, народных праздников. На таких досугах дети учатся делиться на команды, выбирать капитана, согласовывать свои действия с командой, выполнять движения под музыку. На досугах в форме соревнований предусматривается ведущий, жюри. Включаются элементы спортивных игр, соревнования на двух- или трехколесных велосипедах, самокатах. Для физкультурных народных праздников необходима народная атрибутика, костюмы, платки, записи народной музыки.

Региональный модуль дошкольного образования «Мы в Мордовии живем», вариативно реализуемый во всех дошкольных образовательных организациях Республики Мордовия предполагает использование культурных традиций, обычаев мордовского народа в процессе воспитания и обучения дошкольников [4].

Традиции физического воспитания мордвы уходят корнями в глубокую древность. Народная система воспитания мордвы была направлена на формирование необходимых в жизни физических умений и навыков, укрепление здоровья детей. Основным средством физического воспитания детей служили подвижные игры. С их помощью они получали первоначальное физическое развитие, учились ходить, вставать, садиться, бегать. Многие игры выполнялись с игрушками: с мячиком, куклой, специальными палочками, камушками и т. д. [5, с. 452]. Исполняя элементарные физические упражнения, у детей развиваются подвижность и быстрота реакции, находчивость и сообразительность, внимательность и наблюдательность. Игры и физические упражнения проходили в основном на свежем воздухе: в поле, на лугу, в лесу или просто на улице. В зависимости от сезона делились на зимние, весенние, летние, осенние.

К основным подвижным играм мордовского народа, рекомендуемым региональным модулем программы «Мы в Мордовии живем» относятся: «В жгуты» («Пракста карькссэ»), «В ворона» («Чомболкскесэ»), «В горшочки» («Чакшкесэ»), «В курочки» («Саразкесэ»), «В капусту» («Капста прясо»), «Платочки» («Пацинеть»), «В крючки» («Кечказсо»), «В бабушкин платок» («Бабань киресэ»), «Наша гора!» («Минек пандось!»), «Разорви цепь!» («Сезик рисьменть!»), «Останови колесо!» («Лоткавтык калдорушканть!»), «Звонкие камешки» («Щёлксо»), «Войди в дом!» («Совак кудос!»), «Круговой мяч» («Кирькс оска»), «В шар» («Шарсо (жарсо)») и другие.

К числу хороводных игр относятся: «Зазыв весны» («Тундонь тердема»), «Летели птичьи стаи» («Ливтясть нармунь полкт»), «Плетень» («Пирявкске»), «Завивание венка» («Каштаз (венець) пурдамо»), «Рос на поле белый лен» («Каснесь паксяс ашо лён») и другие.

Так, например, мордовская подвижная народная игра «Круговой мяч» («Кирькс оска») может применяться при проведение физического досуга в старшей и подготовительной группах, решая задачи совершенствования умений и навыков владения мячом; развития ловкости, выносливости, меткости, координации в пространстве, быстроты реакций, двигательных и коммуникативных способностей, закрепление и совершенствование.

Для хороводных мордовских народных игр «Зазыв весны», «Плетень» необходимы народные мордовские костюмы, платки, бумажные силуэты жаворонков, записи мордовской народной музыки, глиняные свистульки.

Играя в игру «Зазыв весны» дети разбиваются на две группы - жаворонков и крестьян. У «жаворонков», как отличительный знак птиц - большие платки. В игре «Плетень» дети, взявшись за руки, образуют общий широкий круг. По сигналу педагога дети хором говорят: «Заплетись, плетень!». Включается мордовская народная музыка. В середине хороводной цепи в противоположных частях круга образуется двое ворот. Хоровод разрывается на две части; одна проходит через одни ворота, другая - через другие.

По выходе из ворот каждый участник хоровода правую руку кладет на плечо впереди идущего товарища, левую руку кладет на свое правое плечо - «сплетается плетень». Два полукруга превращаются в круги, которые несколько раз проходят через ворота, соприкасаясь при прохождении, плечами друг с другом.

Музыкальное сопровождение является важной частью в организации физического досуга.

Данные игры способствует не только физическому развитию, но и имеют большое познавательное значение для дошкольников. Дети закрепляют представления о весне, ее особенностях, отличительных чертах как времени года; знакомятся с национальными традициями мордовского народа.

Таким образом, в практике дошкольной образовательной организации при организации физического досуга на национальной основе необходимо использовать разнообразные народный подвижные и хороводные игры, соревнования по метанию мяча, перетягиванию палки и каната, игру в мяч. Неотъемлемой частью при проведении физического досуга на основе национального материала в детском саду должны стать элементы народного костюма, предметы быта и народных промыслов. Их использование помогает детям глубже познакомиться с особенностями национальной культуры, 
ощутить свою сопричастность к ней. С этой же целью можно использовать малые фольклорные формы: игровые зачины и диалоги, считалки, прибаутки, потешки, короткие песни и т.п. В них эмоционально отражается мудрость народа, его физические и нравственные идеалы человека, представленные в краткой, лаконичной, ритмичной форме, что также демонстрирует красоту и богатство родного языка.

\section{ЛИТЕРАТУРА}

1. Бурляева, О.В. Воспитание детей дошкольного возраста на региональном материале в условиях реализации ФГОС дошкольного образования: глава в монографии // Научно-методическое сопровождение реализации ФГОС в условиях региональной системы общего образования: монография / под ред. Т.И. Шукшиной. Саранск: Мордов. гос. пед. ин-т., 2015. С. 4-22.

2. Зацепина М.Б. Культурно-досуговая деятельность в детском саду. Программа и методические рекомендации. Для работы с детьми 2-7 лет. М.: МозаикаСинтез, 2008.86 c.

3. Кенеман А.В., Хухлаева Д.В. Теория и методика физического воспитания детей дошкольного возраста : учеб. пособие для студентов пед. ин-тов по спец. «Дошкольная педагогика и психология». М.: Просвещение, 1978. 272 с.

4. Мы в Мордовии живем: региональный образовательный модуль дошкольного образования: учебно-методическое пособие / Сост. 0.В. Бурляева, Е.Н. Киркина, Т.Н. Кондратьева, Л.П. Карпушина [и др.]; Саранск: Мордов. гос. пед. ин-т., 2015. 80 с.

5. Тихонова В.М. Народные традиции воспитания детей у мордвы // Современные проблемы преподавания башкирского языка в Республике Башкортостан и других регионах российской федерации. Уфа: Изд-во Башкирский государственный университет, 2020. С. 451-455

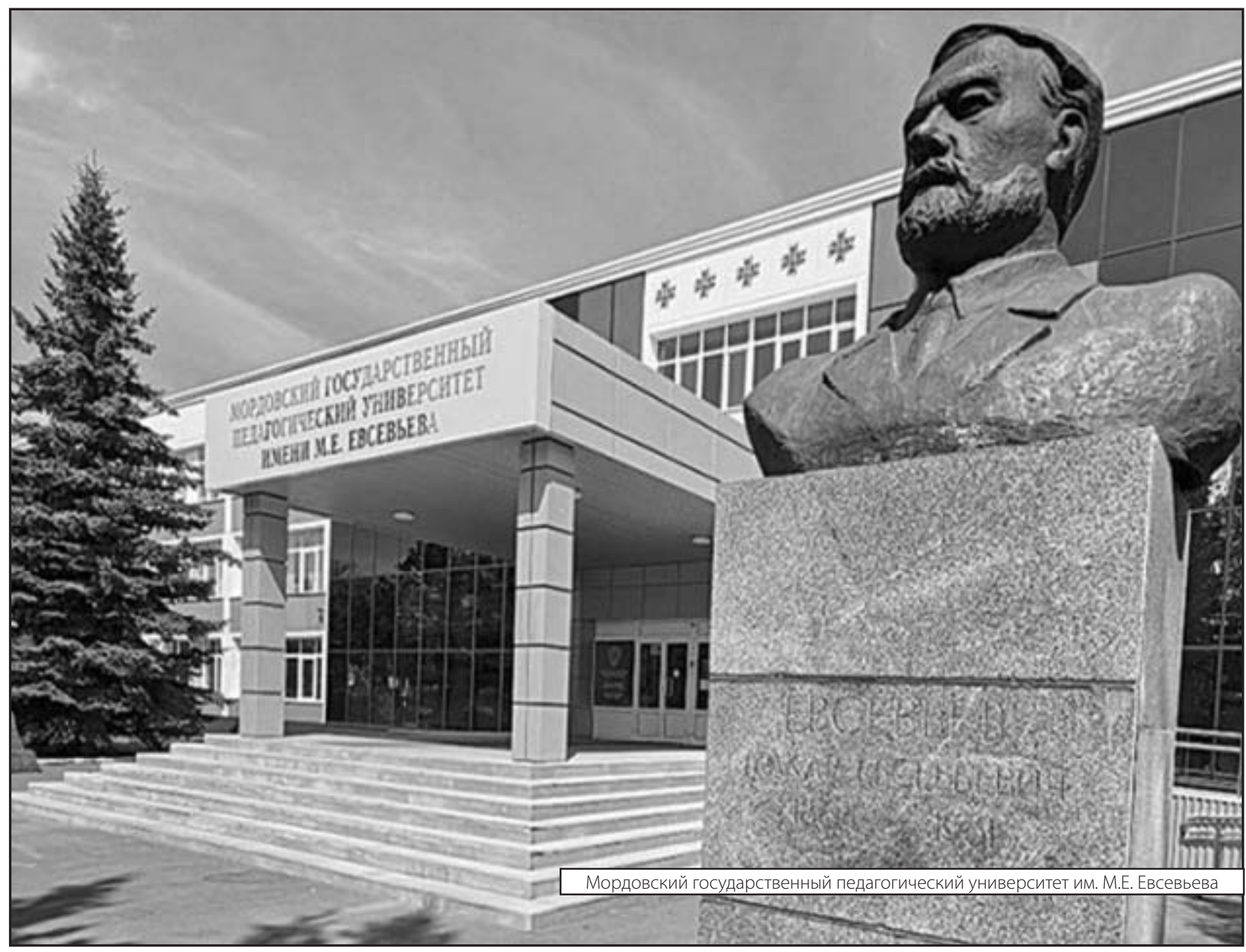

